\title{
Does Government Debt Promote Economic Growth? An Empirical Analysis with Structural Breaks for the Economy of China
}

\author{
Stylianou Tasos $^{1}$
}

This paper investigates the relationship between economic growth and government debt for one of the biggest economies in the world, the economy of China. The data were fitted into a regression equation using econometric techniques such as unit root tests and Granger causality. Regarding unit root tests we are using three kind of tests: i) The conventional unit tests, which do not take into account structural breaks, ii) the unit root tests that take into account one structural break and iii) tests that take into account multiple structural breaks. The analysis is based on data over the period 1984 to 2011 for China. The results reveal that there are structural breaks in the economy of China but no Granger causality between the variables.

Keywords Economic growth; Government Debt, Unit Root tests, Structural Breaks, Bai Perron Test, Granger causality.

JEL Classifications: A10; C32; N15; O40;

\footnotetext{
${ }^{1}$ Stylianou Tasos, University of Macedonia, Department of Applied Informatics Email : tasosstylianou@gmail.com
} 


\section{Introduction}

The impact of public debt on economic growth is one of the most long standing subjects in the history of macroeconomics. Nowadays the policy makers around the world are facing increasing fiscal imbalances, so the relation between these variables has become crucial for the economies.

In economic theory, it is accepted that with a typical Keynesian behaviour, fiscal policy may induce economic growth at moderate levels of public debt. As we are moving at high levels of public debt, the increases of the expected tax will reduce the positive effects of public spending, it will decrease the all the consumption expenses and the investments and finally we will have lower growth rates and less employment. Also in the economic literature there is a clear consensus view that, with lower levels of growth we have less public revenue and more public expenditure, which lead and contribute to the increasing of public debt.

\section{Literature Review}

The literature on the relevance of government debt and economic growth is scarce. Most of the studies are emphasizing in the impact of external debt and debt restructuring on economic growth in developing countries, while analyses for developed countries are virtually absent. Analyses like that become even more relevant as many governments around the world are facing mounting fiscal pressures, with the financial and economic crisis to be so close.

The theoretical literature on the relationship between public debt and economic growth tends to point to a negative relationship. Growth models augmented with public agents issuing debt to finance consumption or capital goods tend to exhibit a negative relationship between public debt and economic growth, particularly in a neoclassical setting.

The empirical evidence on the relationship between debt and growth is primarily focused on the role of external debt in developing 
countries. Several recent studies find support for a non-linear impact of external debt on growth. Pattillo et al. (2002) used a large panel dataset of 93 developing countries for the period 1969-1998. They found that the impact of external debt on per-capita GDP growth is negative for net present value of debt levels above $35-40 \%$ of GDP. Also Clements et al. (2003) used a panel of 55 low-income countries for the period 1970-1999. They found that the turning point in the net present value of external debt is at around $20-25 \%$ of GDP. Other empirical studies that find a non-linear effect of external debt on growth are those of Smyth and Hsing (1995) and Cohen (1997). On the other hand, in his study Schclarek (2004) found that there was a linear negative impact of external debt on per-capita growth in a panel of 59 developing countries for the period 1970-2002.

According to (Feldstein, 1982); (Hoelscher, 1986); (Abell, 1990); (Miller and Russek, 1996); (Raynold, 1994); (Tanzi and Fanizza, 1995); (Cebula, 1993 and 1997); (Svensson, 1997); (Mitra, 1997); and (Vamvoukas, 1997) government debt increases interest rates, and as a consequence is an obstacle to the entrepreneurial activities (Georgiou, 2009b). Schclarek (2004) in his study investigated the relationship between gross government debt and per capita GDP growth in developed countries, but he didn't find any robust evidence of significant relationship. In a recent paper Reinhart and Rogoff (2010), analyze the developments of public debt and the long-term real GDP growth rate in 20 developed countries for a period that cover about two centuries $(1790$ - 2009). They found that the relationship between government debt and long-term growth is weak for debt/GDP ratios below $90 \%$ of GDP; above $90 \%$, the median growth rate is falling by $1 \%$ and the average by considerably more.

Debt can influence economic growth with another channel, the channel of total factor productivity (TFP). This idea has been expressed by Patillo (2004) and many other researchers. According to the theory of productivity we can link debt and growth. It has been 
stated that as a country funds its deficits by foreign external debt, it dedicates a larger fraction of the future output to foreign entities. This in turn can reduce the incentives for higher productivity as people will not be motivated to innovate and become more efficient because foreign investors would benefit most. With dangerously high levels of debt, investments decrease and uncertainty increases. This change in expectations has a structural change in investments, which become predominantly short-term rather long-term. All these changes have a negative effect on the sustained capital accumulation since the investments bear a higher risk and uncertainty. Intuitively no investor would like to tie a big portion of capital in an investment that may be risky. This may have a negative effect on productivity in the economy. An attempt has been made to incorporate debt in the Solow model for an open economy by Villanueva et al (2006). They found that in the long-run the debt-to-GDP ratio can vary substantially based on differing levels of savings, investments, depreciation and exogenous factors such as perceived risk and required risk premiums from lenders. They assumed that in the long-term projection the equilibrium debt-to-GDP ratio is fixed but it can be altered through the above mentioned factors.

On a recent paper Abbas and Christensen (2007) tried to explore the role of domestic debt markets in economic growth. Their study covered 93 countries over the 1975 to 2004 period and revealed that government debt markets play an increasingly important role in supporting economic development in developing countries.

According the macroeconomic theory the government expenditures should have positive relationship with the level of economic growth. The above theory is supported by the paper of Freeman and Webber (2009). In their paper they found that expenditures such as education, health and nutrition (productive type of expenditure) can leads to the economic growth and returns. We must mention that the returns can only be seen in few years time. Also according to the authors, the 
productive expenditures can give direct impact to the improvement of the well-being the welfare of the citizens. As a result, from all the above we can achieve the higher level of economic growth. However, if most of the parts of the government expenditures are driven to unproductive type of expenditures, then this will result to the economic growth and we will give us a decline (Hayati, 2012).

The majority of the policymakers seem to think that government debt reduces long-run economic growth. This view agreed with the results of the empirical literature which shows that there economic growth and debt are in negative correlation in advanced and emerging economies. The correlation is becoming strong when government debt approaches 100 percent of GDP (Reinhart and Rogoff, 2010a,b; Kumar and Woo, 2010; Checherita and Rother, 2010; Cecchetti, Mohanty and Zampolli, 2011).

In this paper we investigate the causal relationship between the government debt to GDP ratio and economic growth for a big economy like China, for a period from 1984 to 2011.

\section{Data}

This study uses annual time series data on GDP per capital and Gross Government Debt (as percentage on GDP) sourced from IMF (International Monetary Fund). The data covers the period between 1984 and 2011 in China. The logarithm of GDP and Gross Government Debt are used in the analysis. The transformation of the series to logarithms is intended to eliminate the problem of heteroskedasticity

\section{Econometric Methodology}

The basic equation we are using is $G D P_{t}=f\left(D E B T_{t}\right)$ and $G D P_{t}=\beta_{0}+\beta_{1}\left(D E B T_{t}\right)+\mu_{t}$ according the model proposed by Georgiou (2009). In order to avoid spurious regression outcomes on 
the time series data, we are using unit root tests that affirm the stationarity of the series. In this paper we use three kinds of unit roots tests. Firstly we use the traditional unit roots tests which do not take into account structural breaks such as Augmented Dickey-Fuller (ADF) test (Dickey and Fuller, 1979) the Phillips-Perron test (1988) and the test of Kwiatkowski et al. (1992). The second kind of unit root tests we use are the tests that take into account one structural break such as Zivot and Andrews (1992). The third method we use in the paper is the Bai Perron $(1998,2001)$ test for estimating linear regression models subject to multiple breaks. Finally we have used Granger causality analysis in order to investigate the relationship between GDP and Gross Government Debt.

\subsection{UNIT ROOT TESTS WITHOUT STRUCTURAL BREAKS} ADF test

$$
\begin{aligned}
& \Delta y_{t}=c+\alpha y_{t-1}+\sum_{j=1}^{k} d_{j} \Delta y_{t-j}+\varepsilon_{t} \\
& \Delta y_{t}=c+\alpha y_{t-1}+\beta_{t}+\sum_{j=1}^{k} d_{j} \Delta y_{t-j}+\varepsilon_{t}
\end{aligned}
$$

The first equation (1) tests the null of a unit root against a mean stationarity in yt ( $y$ is the time series we examine each time). The second equation (2) tests the null of a unit root against the alternative of trend stationarity ( $\Delta \mathrm{Y}_{\mathrm{t}-\mathrm{j}}$ is lagged first differences)

\section{PHILLIPS PERRON TEST}

The PP test (1988) makes the semi -parametric correction for autocorrelation and its more powerful in the case we have weakly autocorrelation and heteroskedastic regression residuals. We can say that Phillips Perron test is an extension of the ADF test.

KPSS TEST

Unlike most of the unit root tests Kwiatkowski-Phillips-Schmidt-Shin (1992) provide a test where the null hypothesis is that a series is stationary. The test has been developed to complement unit root tests 
as the last have low power with respect to near unit root and long run trend process.

\subsection{UNIT ROOT TESTS WITH STRUCTURAL BREAKS}

4.2.1 Zivot and Andrews Model:

Zivot and Andrews (1992) proceed with three models to test for a unit root: model A, which permits a one-time change in the level of the series; model B, which allows for a one-time change in the slope of the trend function, and model $\mathrm{C}$, which combines one-time changes in the level and the slope of the trend function of the series. The 3 models are:

$$
\begin{aligned}
& \Delta Y_{t}=\kappa+\alpha^{*} Y_{t-1}+\beta^{*} t+\theta_{1} D U_{t}+\sum_{j=1}^{k} d_{j} \Delta Y_{t-j}+\varepsilon_{t} \quad \text { (Model A) } \\
& \Delta Y_{t}=\kappa+\alpha^{*} Y_{t-1}+\beta^{*} t+\gamma_{1} D T_{t}+\sum_{j=1}^{k} d_{j} \Delta Y_{t-j}+\varepsilon_{t} \text { (Model B) } \\
& \Delta Y_{t}=\kappa+\alpha^{*} Y_{t-1}+\beta^{*} t+\vartheta_{1} D U_{t}+\gamma_{1} D T_{t}+\sum_{j=1}^{k} d_{j} \Delta Y_{t-j}+\varepsilon_{t} \text { (Model C) }
\end{aligned}
$$

DUt is an indicator dummy variable for a mean shift occurring at each possible break-date (TB) while DTt is corresponding trend shift variable

$$
D U_{t}=\left\{\begin{array}{cc}
1 & \text { if } t \succ T B \\
0 & \text { otherwise }
\end{array} \quad \text { and } \quad D T_{t}=\left\{\begin{array}{c}
t-T B \quad \text { if } t \succ T B \\
0 \quad \text { otherwise }
\end{array}\right.\right.
$$

The null hypothesis in all the models is that $\alpha=0$, which means that the series $\{y t\}$ contains a unit root with a drift that excludes any structural break. The alternative hypothesis is that $\alpha<0$. It implies that the series is a trend-stationary process with a one-time break occurring at an unknown point in time.

The Bai-Perron Method 
Bai and Perron $(1998,2001)$ proposed a method for estimating linear regression models subject to multiple breaks. The model assumes that the dependent variable, $\mathrm{yt}$, is related to a set of state variables, $\mathrm{x}_{\mathrm{t}-1}$ but that the relationship has been subject to $\mathrm{q}$ breaks up to time $\mathrm{T}$ :

$$
\begin{array}{rlrl}
y_{t} & =\beta_{1}^{\prime} x_{t-1}+\hat{u}_{t} & t & =1,2, \ldots, T_{1} \\
y_{t} & =\beta_{2}^{\prime} x_{t-1}+\hat{u}_{t} & t & =T_{1}+1, \ldots, T_{2} \\
y_{t} & =\beta_{q+1}^{\prime} x_{t-1}+\hat{u}_{t} & t & =T_{q}+1, \ldots, T
\end{array}
$$

$T_{1} \prec T_{2} \prec \ldots \prec T_{q} \prec T$ and Ut is a disturbance term. The Bai and Perron method permits consistent estimation of the number and location of the breakpoints and the parameters.

The model it's possible to be restricted to allow partial breaks that only affect some of the regression coefficients. Because the breaks are viewed as deterministic and the approach thus does not require specifying the underlying process that generated the breaks in the first place. The approach relies on a number of design parameters such as the maximum number of breaks and the minimum distance between breaks.

We can determine the number of the breaks with many ways. One approach is to determine the number of breaks sequentially by testing for $\mathrm{q}+1$ against $\mathrm{q}$ breaks. Alternatively a global approach of testing for q breaks against no breaks can be used. Finally, the number of breaks can be selected by using penalized likelihood methods such as the Schwarz information criterion (SIC) or Akaike's information criterion (AIC) which differ in terms of the penalty they apply to the inclusion of additional breakpoint parameters. All of the above and other practical issues are further discussed in Bai and Perron (2001).

\subsection{GRANGER CAUSALITY TEST}

The test procedure as described by (Granger 1969) is illustrated below:

$$
G D P=\sum_{j=1}^{K} A_{j} E D_{t-i}+\sum_{j=1}^{K} B_{j} G D P_{t-j+U i t}
$$




$$
D E B T=\sum_{j=1}^{K} C_{i} D E B T_{t-i}+\sum_{j=1}^{K} D_{j} G D P_{t-j+U 2 t}
$$

Equation (3) represents that current GDP is related to past values of itself as well as that of DEBT and vice- versa for Eq. (4).Unidirectional causality from DEBT to GDP is indicated if the estimated coefficient on the lagged DEBT in equation (3) are statistically different from zero as a group and the set of estimated coefficients on the lagged GDP in Eq. (4) is not statistically different from 0 .The converse is the case for unidirectional causality from GDP to DEBT. Bilateral causality exists when the sets of DEBT and GDP coefficient are statistically different from 0 in both regressions (Gujarati, 2004). (Note: we are using the variables in first differences).

\section{Empirical Results}

Unit Root Tests without Structural Breaks

In order to guard against spurious regression we have to find whether our variables are stationary or non stationary. So we applied unit root tests to check the stationarity. The results of the tests we have used are presented in Table 1. We have expressed our variables in natural logarithms so that elasticities can be determined.

Insert Table 1

All the unit root tests (without structural break) have shown that our variables are integrated of order I (1).

Zivot Andrew's Results

In Table 2 we represent the results for Zivot and Andrew's unit root test (with one structural break). The results suggest that we can reject the null of unit root for the variables of DEBT and GDP (with statistical significance at level $10 \%$ ). At the same time, the test identifies endogenously the point of the most significant structural break in every time series examined in the paper. The Break point for the variable of DEBT is 1998 (Figure 1), since 1998 was the year of the Asian financial crisis. The Break point for the variable of GDP is 
2005 (Figure 2). If we move back to 2005 in the economic history of China we can find that in 2005, regulations that prevented privatelyowned companies entering a number of sectors of the economy, such as infrastructure, public utilities and financial services were abolished. With this decision further improvement in multifactor productivity was possible. All these changes have permitted the emergence of a powerful private sector in the economy.

\section{Results of Bai-Perron's breakpoint test}

The next test we had obtained was the Bai-Perron's breakpoint test. In Table 3 we report the optimal number of breakpoints (i.e the one associated with the minimum BIC score or the maximum Log - Lik score). The optimum number of breakpoints we have in our model is 4 and the breaks were in the years 1989, 1993, 2002 and 2007.

\section{Granger Causality Test}

After the stationarity we proceed to find the causality using the Granger causality test. Table 4 presents our findings. From the results there is no evidence that there is any causality between Government Debt (DEBT) and economic growth (GDP) in China. We can state that government debt is not a specific factor determining the rate of economic growth or economic slowdown in China.

\section{Conclusions}

In this paper we empirically examined the relationship between economic growth and government debt for the economy of China. In order to test the stationarity of our variables we have used two kinds of unit root tests. The traditional unit roots tests which do not take into account structural breaks such as Augmented Dickey-Fuller (ADF) tests (Dickey and Fuller, 1979 and 1981) the Phillips-Perron test (1988) and the test of Kwiatkowski et al. (1992). The results have shown that our variables are stationary of order one. The second kind 
of unit root tests we have used are the tests that take into account one structural break such as Zivot and Andrews test (1992). The Zivot and Andrews's test indicated that the Break point for the variable of DEBT was 1998 and for the variable of GDP was 2005.

After the unit root tests we have tested our model with Bai Perron's test. The Bai Perron's method $(1998,2001)$ is using for estimating linear regression models subject to multiple breaks. The test has shown that the optimum number of breakpoints we have is 4 and the breaks were in years 1989, 1993, 2002 and 2007. Finally we have used Granger causality analysis in order to investigate the relationship between our variables. The results suggested that we cannot establish causality between government debt and growth in China.

The first aim of the paper was to contribute to the empirical literature on the effects of government debt to economic growth. Our findings are in line with the results of Schclarek's (2004) survey where he didn't find any robust evidence of significant relationship between gross government debt and per capita GDP growth in developed countries. Also our results agree with the results of Reinhart and Rogoff (2010), where they found that the relationship between government debt and long-term growth is weak for debt/GDP ratio. The second aim of this paper was to examine the economy of China for structural changes during the last decades. Our results indicated that China (regarding the variable of growth and the variable of government debt) is clearly characterized by dynamic transformations. The economy of China has been affected by critical economic incidents that lead the variables of GDP and government debt to yield structural breaks. 


\section{References:}

Abbas, S. M. A. and Christensen, J. E., (2007), "The Role of Domestic Debt Markets in Economic Growth: An Empirical Investigation for Low income Countries and Emerging Markets". IMF Working Paper no.127

Abell, J. D. (1990), "Twin deficits during the 1980s: An empirical investigation", Journal of Macroeconomics 12, pp 81-96.

Bai, J. and Perron, P. (1998), "Estimating and testing linear models with multiple structural changes", Econometrica, Vol. 66, pp. 47-78.

Bai, J. and Perron, P. (2001), "Multiple structural change models: A simulation analysis", Boston University, Manuscript.

Cebula, R. J. (1993), "An empirical analysis of federal budget deficits and interest rates directly affecting saving and loans", Southern Economic Journal, 60, pp 28-35.

Cebula, R. J. (1997). "An empirical note on the impact of the federal budget deficit on ex ante real long-term interest rates, 1973-1995". Southern Economic Journal 63, pp 1094-9.

Cecchetti, Stephen, Madhusudan Mohanty and Fabrizio Zampolli. (2011), "The real effects of debt", BIS Working Paper 352 Bank for International Settlements.

Checherita, Cristina and Philipp Rother (2010), “The impact of high and growing government debt on economic growth: an empirical investigation for the euro area", Working Paper Series 1237 European Central Bank.

Cohen, D. (1997), "Growth and external debt: A new perspective on the African and Latin American tragedies", Centre for Economic Policy Research Discussion Paper No. 1753.

Clements, B., R. Bhattacharya and T. Q. Nguyen (2003), "External debt, public investment, and growth in low-income countries", IMF Working paper $03 / 249$. 
Dickey, D. A. and Fuller, W. A., (1979), "Distributions of the estimators for autoregressive time-series with a unit root", Journal of the American Statistical Association, 74 (3), pp. 427-431.

Dickey, D.A. and Fuller, W.A., (1981). "Distribution of the estimators for autoregressive time series with a unit root". Econometrica 49, pp. 1057--72.

Feldstein, M. (1982), "Government deficits and aggregate demand", Journal of Monetary Economics 9, pp 1-20.

Freeman S. M., and Webber D. J. (2009), "Basic needs, government debt and economic growth," The World Economy., vol. 32, no. 6, pp. 965-994.

Georgiou, M. N. (2009a), "Government Debt and Economic Growth. Some Comments. A Panel Data Analysis for Western Europe (1988 2006)", Social Science Research Network (SSRN).

Georgiou, M. N. (2009d), "Financial Deepening and Unemployment", Social Science Research Network (SSRN), Available at. http://papers.ssrn.com/sol3/papers.cfm?abstract_id=1478630

Granger, C.W.J. (1969). "Investigating causal relation by econometric and cross-sectional method", Econometrica 37: 424-438.

Gujarati, D.N. (2004). "Basic Econometrics", 4th ed. McGraw-Hill Book Co.

Hoelscher, G. (1986), "New evidence on deficits and interest rates", Journal of Money, Credit and Banking 18, pp 1-17.

Kumar, Manmohan S. and Jaejoon Woo (2010), "Public Debt and Growth", IMF Working Papers 10/174 International Monetary Fund.

Kwiatkowski, D., Phillips, P.C., Schmidt, P., \& Shin, Y. (1992) "Testing the null hypothesis of stationarity against the alternative of a unit root". Journal of Econometrics, 54, pp 159 - 178.

Miller, S. M., \& F. S. Russek, Jr. (1996), "Do federal deficits affect interest rates? Evidence from three econometric methods", Journal of Macroeconomics 18, pp 403-28. 
Mitra, S. (2007), "Is the Quantity Of Government Debt a Constraint for Monetary Policy?", International Monetary Fund Working Paper no. 0762, March.

Nur Hayati A. R. (2012), "The relationship between budget deficit and economic growth from Malaysia's perspective," in International Proceedings of Economics Development and Research, Singapore, 2012, pp. 5458.

Pattillo, Catherine A., Helene Poirson, and Luca Antonio Ricci (2002), "External debt and growth." IMF W orking Papers 02/69, International Monetary Fund

Pattillo, Catherine; Helene Poirson and Luca Ricci. 2004. "What Are the Channels through Which External Debt Affects Growth," International Monetary Fund (IMF).

Phillips, P.C.B, and P. Perron (1988), "Testing for a Unit Root in Time Series Regressions" Biometrika 75, pp 335-346.

Reinhart, C. M. and K. S. Rogoff (2010), "Growth in a Time of Debt", NBER Working Paper No. 15639.

Raynold, P. (1994), "The impact of government deficits when credit markets are imperfect: evidence from the interwar period", Journal of Macroeconomics 16, pp 55-76.

Reinhart, Carmen M. and Kenneth S. Rogoff (2010a), "Debt and Growth Revisited." VoxEU.org.

Reinhart, Carmen M. and Kenneth S. Rogoff, (2010b), "Growth in a Time of Debt." American Economic Review 100(2):573-78.

Smyth, D. and Hsing, Y. (1995), "In search of an optimal debt ratio for economic growth", Contemporary Economic Policy, 13:51-59.

Schclarek, A. and F. Ramon-Ballester. (2004). "External Debt and Economic Growth in Latin America". Working paper, 2004.

Svensson, L.E.O (1997), "Inflation Forecast Targeting: Implementing and Monitoring Inflation Targets", European Economic Review, 41, pp $1111-1146$

Year XV no. 46

December 2012 
Tanzi, V. and D. Fanizza (1995), "Fiscal Deficit and Public Debt in Industrial Countries (1970 - 1994)", IMF Working Paper, WP/95/49. Available at: www.ssrn.com as id883197.pdf Vamvoukas, G. A. (1997), "A note on budget deficits and interest rates: evidence form a small open economy", Southern Economic Journal 63, pp 803-11.

Villanueva, Delano and Roberto Mariano. (2006), "External Debt, Adjustment and Growth." SMU, School of Economics and Social Sciences Zivot, E. and Andrews D. (1992), "Further evidence of great crash, the oil price shock and unit root hypothesis", Journal of Business and Economic Statistics, 10, pp 251-270. 


\section{Annexes:}

Table 1

\section{Unit Root Tests}

\begin{tabular}{|l|l|l|l|l|l|l|l|}
\hline & \multicolumn{4}{|l}{ Dickey - Fuller } & \multicolumn{2}{l|}{ Phillips - Perron } & \multicolumn{2}{l|}{ KPSS } \\
\hline & $\tau_{\mu}$ & $\tau_{\tau}$ & & $\tau_{\mu}$ & $\tau_{\tau}$ & $\eta_{\mu}$ & $\eta_{\tau}$ \\
\hline LGDP & 0.637 & -3.251 & 1 & 0.763 & -1.760 & $0.675^{* *}$ & $0.115^{* * *}$ \\
& {$[0.988]$} & {$[0.066]$} & & {$[0.991]$} & {$[0.696]$} & & \\
\hline LDEBT & $-2.870 *$ & $-3.517 *$ & 1 & $-2.710^{*}$ & $-3.514 *$ & $0.669 * *$ & $0.192^{* *}$ \\
& {$[0.041]$} & {$[0.046]$} & & {$[0.041]$} & {$[0.038]$} & & \\
\hline$\Delta$ LGDP & $-3.546^{* *}$ & $-3.567 *$ & 0 & -2.984 & -3.734 & 0.122 & 0.052 \\
& {$[0.015]$} & {$[0.053]$} & & $* *$ & $* *$ & & \\
& & & & {$[0.049]$} & {$[0.042]$} & & \\
\hline$\Delta$ LDEBT & - & -7.878 & 0 & -8.083 & -7.878 & 0.262 & 0.103 \\
& $8.083^{* * *}$ & $* *$ & & $* * *$ & $* * *$ & & \\
& {$[0.000]$} & {$[0.000]$} & & {$[0.000]$} & {$[0.000]$} & & \\
\hline
\end{tabular}

Notes:

$\tau_{\mu}$ is the t-statistic when a time trend is not included in the equation and $\tau_{\tau}$ is the tstatistic when a time trend is included in the equation. The calculated statistics are those reported in Dickey-Fuller (1981). The critical values for the tests of Dicky - Fuller and Phillips - Perron are at $1 \%-3.711$, at $5 \%-2.981$ and at $10 \%-2.630$ for $\tau_{\mu}$ and $-4.47,-3.65$ and -3.26 for $\tau_{\tau}$ respectively.

$\eta_{\mu}$ and $\eta_{\tau}$ are the KPSS statistics for testing the null hypothesis that the series are I(0) when the residuals are computed from a regression equation with only an intercept and intercept and time trend, respectively. The critical values at $1 \%, 5 \%$ and $10 \%$ are 0.739 , 0.463 and 0.347 for $\eta_{\mu}$ and $0.216,0.146$ and 0.119 for $\eta_{\tau}$ respectively (Kwiatkowski et al, 1992, table 1).

***, **, * indicate significance at the 1,5 and 10 percentage levels. 


\section{Table 2}

Zivot Andrew's test

\begin{tabular}{|lcc||l|l|}
\hline & & & t-Statistic & Break Point \\
\hline Zivot-Andrews & test & statistic & & \\
(DLGDP) & & & -4.712704 & 2005 \\
Zivot-Andrews & test & statistic & & \\
(DLDEBT) & & & -8.394546 & 1998 \\
$1 \%$ critical value: & & & -5.34 & \\
$5 \%$ critical value: & & -4.93 & \\
$10 \%$ critical value: & & -4.58 & \\
\hline
\end{tabular}

Table 3

Bai-Perron Breakpoints Test

\begin{tabular}{|c|c|c|c|c|c|c|}
\hline Breakpoints & 0 & 1 & 2 & 3 & 4 & 5 \\
\hline $\mathrm{BIC}$ & 14.62549 & 8.736564 & -7.646532 & -14.42801 & -21.72394 & -18.21867 \\
\hline Log-Lik & -0.721071 & 8.815066 & 23.59829 & 33.58070 & 43.82034 & 48.65938 \\
\hline RSS & 1.667578 & 0.822828 & 0.275254 & 0.131401 & 0.061545 & 0.043005 \\
\hline N. Coefs & 4.000000 & 8.000000 & 12.00000 & 16.00000 & 20.00000 & 24.00000 \\
\hline \multicolumn{7}{|c|}{ Chosen number of breaks: 4} \\
\hline \multirow[t]{4}{*}{ Breaks : } & 1989 & & & & & \\
\hline & 1993 & & & & & \\
\hline & 2002 & & & & & \\
\hline & 2007 & & & & & \\
\hline
\end{tabular}


Table 4

\section{Pairwise Granger Causality Tests}

F-

Null Hypothesis:

Obs Statistic Prob.

DLGDP does not Granger Cause

DLDEBT $25 \quad 0.890090 .4263$

DLDEBT does not Granger Cause DLGDP

Figure 1

Zivot - Andrew's Breakpoint DLDEBT (1998)

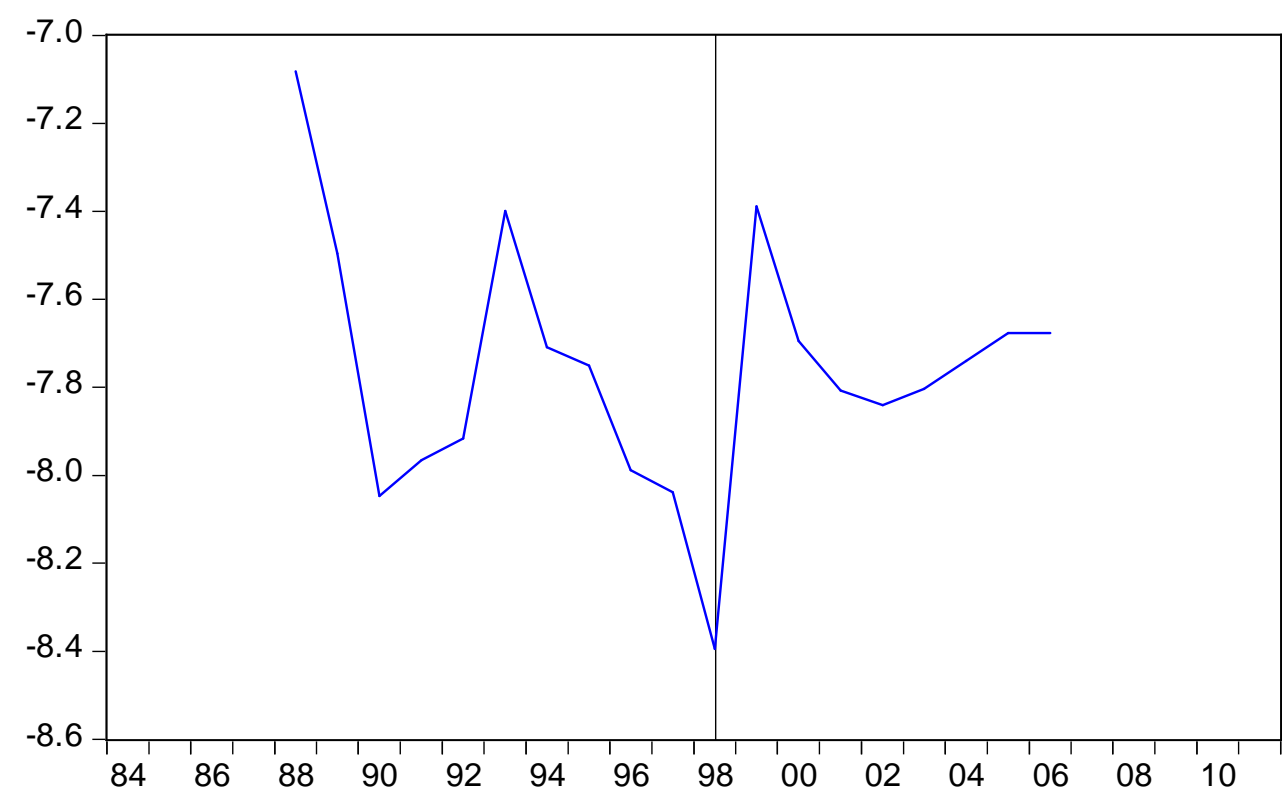


Figure 2

Zivot - Andrew's Breakpoint DLGDP (2005)

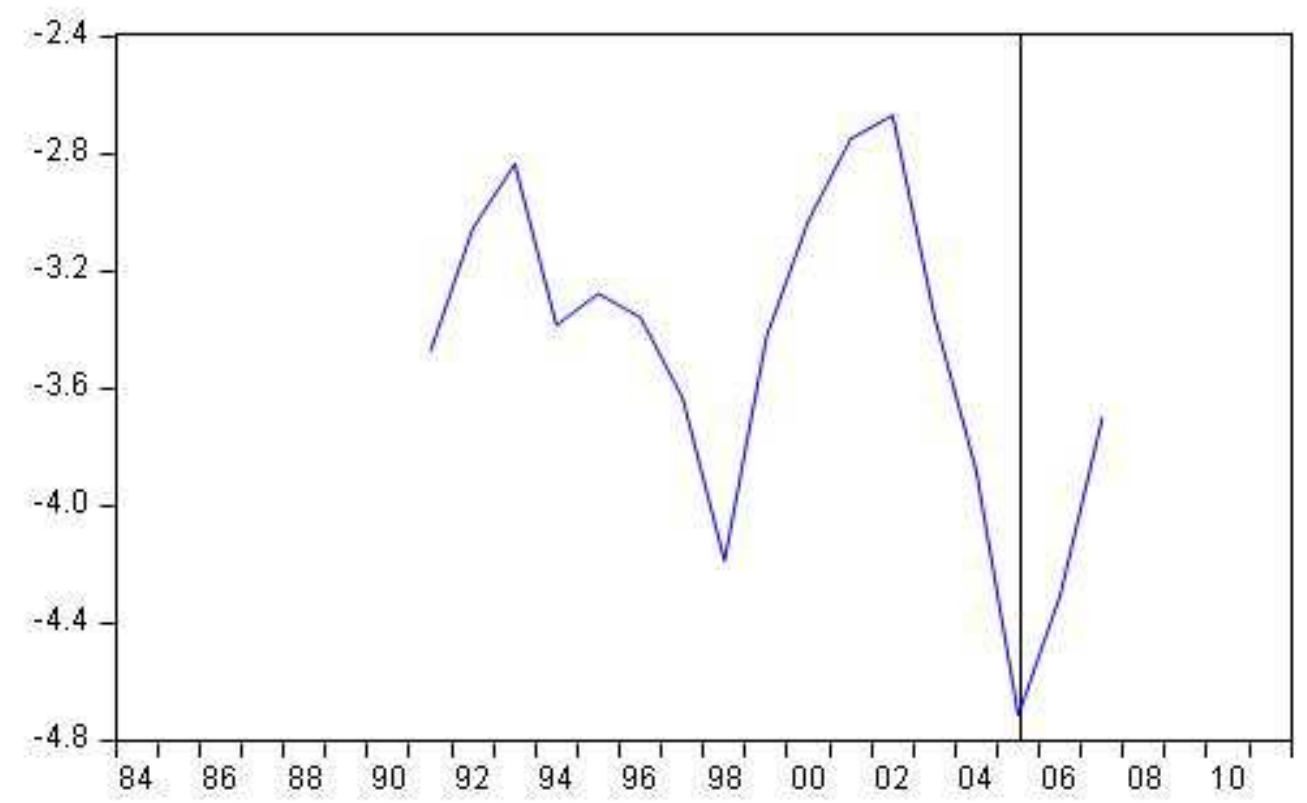

Year XV no. 46

December 2012 
